\title{
Evaluation of the environmental parameters of battery-caged poultry house in the humid tropical climate
}

\author{
Evaluación de los parámetros ambientales de la casa de aves de corral \\ enjaulada por batería en el clima tropical húmedo.
}

Jongbo AO. Evaluation of the environmental parameters of battery-caged poultry house in the humid tropical climate. Rev Colombiana Cienc Anim. Recia. 2020; 12(2):e753. https://doi.org/10.24188/ recia.v12.n2.2020.753

Universidad de Sucre, Colombia

Los autores permiten a RECIA reimprimir el material publicado en él. En caso de que un autor quiera traducir o usar una publicación parcial o completa de nuestro Diario, el autor debe obtener un permiso por escrito del editor de la revista.

Copyright (C) 2020. El (los) autor (es), Revista Colombiana de Ciencia Animal - RECIA. 2020. Este es un artículo de acceso abierto distribuido bajo los términos de Creative Commons Attribution 4.0 (https://creativecommons.org/licenses/by-nc-sa/4.0/), El uso, distribución o reproducción está permitido, siempre que se acrediten al autor original y al propietario del copyright y que se cite la publicación original en esta revista, de acuerdo con la práctica académica aceptada. No se permite el uso, distribución o reproducción que no cumpla con estos términos.

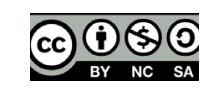




\title{
Evaluation of the environmental parameters of battery-caged poultry house in the humid tropical climate
}

\author{
Evaluación de los parámetros ambientales de la casa de aves de corral enjaulada por \\ batería en el clima tropical húmedo
}

Ayoola Olawole Jongbo, Ph.D.

Federal University of Technology, School of Engineering and Engineering

DOI: https://doi.org/10.24188/recia.v12.n2.2020.753

Technology, Department of Agricultural and Environmental Engineering, PMB 704, Akure, Ondo State, Nigeria.

aojongbo@futa.edu.ng aojongbo@gmail.com

(i) https://orcid.org/0000-0003-1603-5876

Recepción: 11 marzo 2020

Aprobación: 26 junio 2019

Publicación: 3 julio 2020

\begin{abstract}
Heat stress is a key factor affecting the productions of the animals. In laying birds, it could cause loss of body weight and high mortality. To this end, a study was carried out in a naturally ventilated, tier-caged layer house to evaluate the environmental parameters and the heat stress index within the building during hot weather period. Throughout the study, the environmental parameters (air temperature, relative humidity and air velocity), inside and outside the experimental building were measured and recorded. The heat stress index using the temperature-humidity index (THI) was also estimated. The results of the study indicated that laying birds in this study were most of their lifetime subjected to hot conditions which could have a significant effect on their performances. It was also found out that the air velocity within the building was very low $\left(0.07 \mathrm{~ms}^{-1}\right.$ to $\left.0.58 \mathrm{~ms}^{1}\right)$ which could not provide a cool environment for the birds. The heat stress index (THI) inside laying bird building was found to be mostly influenced by high relative humidity compared to ambient temperature. Therefore, it would be appropriate if the airflow distribution inside the poultry building, in this study, could be evaluated using computational fluid dynamics to understand the velocity profile within the building. This could assist engineers to redesign the building and make it appropriate for laying birds in the humid tropical climate.
\end{abstract}

Keyword: Air temperature; Air velocity; Heat stress; Layer bird; Relative humidity; Temperature-humidity index.

\section{RESUMEN}

El estrés por calor es un factor clave que afecta la producción de los animales. En aves ponedoras, puede causar pérdida de peso corporal y alta mortalidad. Con este fin, se realizó un estudio en una casa de capas enjaulada y ventilada naturalmente para evaluar los parámetros ambientales y el índice de estrés por calor dentro del edificio durante el período de clima cálido. A lo largo del estudio, se midieron y registraron los parámetros ambientales (temperatura del aire, humedad relativa y velocidad del aire), dentro y fuera del edificio experimental. También se calculó el índice de estrés por calor utilizando el índice de temperatura-humedad (THI). Los resultados del estudio indicaron que las aves ponedoras en este estudio estuvieron sometidas la mayor parte de su vida a condiciones de calor que podrían tener un efecto significativo en su desempeño. También se descubrió que la velocidad del aire dentro del edificio era muy baja $\left(0.07 \mathrm{~ms}^{-1} \mathrm{a}^{\left.0.58 \mathrm{~ms}^{-1}\right)}\right.$ lo que no podía proporcionar un ambiente fresco para las aves. Se encontró que el índice de estrés por calor (THI) dentro del edificio de aves ponedoras está influenciado principalmente por la alta humedad relativa en comparación con la temperatura ambiente. Por lo tanto, sería apropiado evaluarse la distribución del flujo de aire dentro del edificio avícola, utilizando la dinámica de fluidos computacional para comprender el perfil de velocidad dentro del edificio. Esto podría ayudar a los ingenieros a rediseñar el edificio y hacerlo apropiado para poner aves en el clima tropical húmedo.

Palabras clave: Temperatura del aire; Velocidad del aire; Estrés por calor; Capa de pájaro; Humedad relativa; Índice de temperatura-humedad. 


\section{INTRODUCTION}

Globally, poultry production (meat and eggs) has been the leading sector in the agricultural industry $(1,2)$. It has recently intensified to meet up with the steady increase in the demand for poultry-based agricultural products $(3,4)$. The population of Nigeria has been estimated to increase to 250 million by the year 2030 (5). However, poultry producers in Nigeria could find it difficult to meet up with the poultry-based products for human consumption due to the climatic condition (humid tropical climate) in the country. Generally, Nigeria is located on latitude $4-14^{\circ} \mathrm{N}$ and longitude $3-15^{\circ} \mathrm{E}$ and the country is known to be warm mostly throughout the year due to high temperatures ranging from 25 to $32^{\circ} \mathrm{C}$ (6). Therefore, providing cool environment for the birds could be challenging as it would require constant availability of power supply which could add to the cost of production of the poultry-based products.

Over the years, many studies have been carried out evaluating the productivity and profitability of poultry egg farming in Nigeria $(7,8,9,10)$. Tijjani et al $(10)$ conducted an economic analysis of poultry egg production in the northern part of Nigeria to estimate the cost incurred in poultry production and the returns. The authors indicated that the main problems in the region (Northern Nigeria) were the cost of feed, poor ventilation and poor veterinary and management practices among others. The prospects and challenges facing large scale poultry production were recently evaluated by Adeyemo and Onikoyi (11). They indicated that the major challenges confronting poultry production were poor feed quality, improper handling of eggs during incubation, high cost of feed, poor veterinary services and poor marketing strategies. In a study carried out by Ezeh et al (12), it was shown that flock size, feed consumption and labour input affected poultry production in the eastern region of Nigeria. It could be observed from the above research works that environmental conditions to which the birds were subjected were not considered. Environmental conditions play a crucial role in animal production and it has been indicated that animal performances could be directly related to the environmental conditions to which they are subjected $(13,14)$.

It has been shown that there are two main factors to control the thermal environment of the poultry building (15). The first is the knowledge of the poultry grower (farmer) about the thermoregulation of the birds. The second focusses on the environmental parameters required by the birds. Lack of understanding of the environment to which poultry birds are subjected could result in high mortality and poor production. The heat stress affecting poultry is majorly caused by the air temperature and relative humidity (16). These parameters have been indicated to be controlled by increasing the air movement within the poultry building. As reported by Blanes-Vidal et al (17), it is not appropriate to raise poultry birds in an environment with low air movement as it could result in heat stress which could cause significant mortality rates (18). This indicates that it is detrimental to raise poultry birds in the environments that would impair their activities (drinking and feeding) and the exhibition of natural behaviours like wing flapping, dust bathing, perching and distribution.

Heat stress in livestock production could be explained as the combination of any environmental parameters (temperature, relative humidity and air velocity) creating conditions that are greater than the temperature range of the thermoregulatory zone of the animals. A change, either temporal or permanent, in the environment to which animals are kept could result in stress. The change could affect feed consumption, feed efficiency, growth rate, meat yield and quality and egg production of laying birds (19). In case of extreme weather conditions, it may be difficult to control heat stress in poultry birds. According to Kapetanov et al (20), it could be difficult to remove warm air surrounding adult birds by providing higher ventilation rate when the relative humidity within the poultry building is high. Many studies have evaluated the level of heat stress in poultry production using heat stress indices $(19,21)$. However, since climatic conditions in different areas differ, there is still a need to evaluate the heat stress to which poultry birds experience based on the environmental conditions to which they are subjected in the humid tropical climate.

Therefore, the objective of this study was to understand the climatic conditions to which poultry birds (layers) are subjected. In addition, the heat stress to which the birds are experiencing was evaluated based on the environmental parameters measured within the layer bird building so as to understand how to create suitable environment for the birds mostly during the hot weather periods. To this end, this study was set up to (1) measure and evaluate the environmental parameters (air temperature, relative humidity and air velocity) in the layer hens building; (2) determine the level of heat stress to which the birds were subjected.

\section{MATERIALS AND METHODS}

Experimental site. The study was carried out at Poultry Research Farm of the Federal University of Technology, Akure, Ondo State, Nigeria. The study area falls between the latitudes $7^{\circ} 17^{\prime} 03^{\prime \prime} \mathrm{N}$ to $7^{\circ} 19^{\prime} 06^{\prime \prime} \mathrm{N}$ and longitudes $5^{\circ} 07^{\prime} 02^{\prime \prime} \mathrm{E}$ to $5^{\circ} 09^{\prime} 05^{\prime \prime} \mathrm{E}$. The area is characterised for having high temperatures ranging from $22^{\circ} \mathrm{C}$ to over $30^{\circ} \mathrm{C}$ throughout the year. 
It also has two major seasons namely; rainy season (April to October) and dry season (November to March). It has an annual rainfall of about $2400 \mathrm{~mm}$, which makes the region to be more humid.

This research study was conducted in one of the naturally ventilated layer houses in the Research Farm. It is the largest house with dimensions $29.5 \mathrm{~m}$ (length), $9 \mathrm{~m}$ (width) and $3.5 \mathrm{~m}$ (height). The house has a one-sided open roof designed to allow heat loss from the building (Figure 1). The house was located at about $7.5 \mathrm{~m}$ away from another house at the windward side (Figure 2) and surrounded by vegetations such as orange tree and plantains at the leeward side and one of its ends respectively. The houses were occupied with three sets of 3-tiered battery cages (Figure 2 and 3). The birds were manually fed by the farm workers while the watering system is automatically controlled. The droppings from the birds fall into about $0.7 \mathrm{~m}$ deep pit directly under the cages and daily washed into an opened outdoor pit where it could either be allowed to decay or used for agricultural purpose.

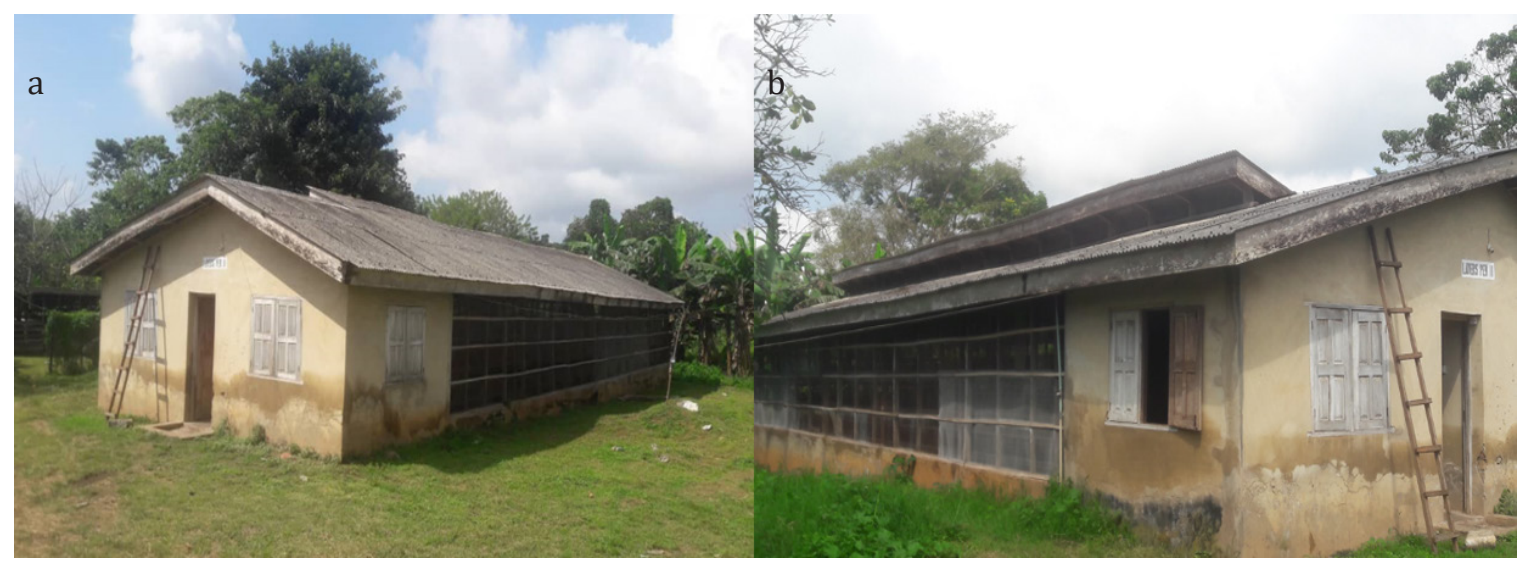

Figure 1. Naturally ventilated poultry building views (a) windward side and (b) leeward side.

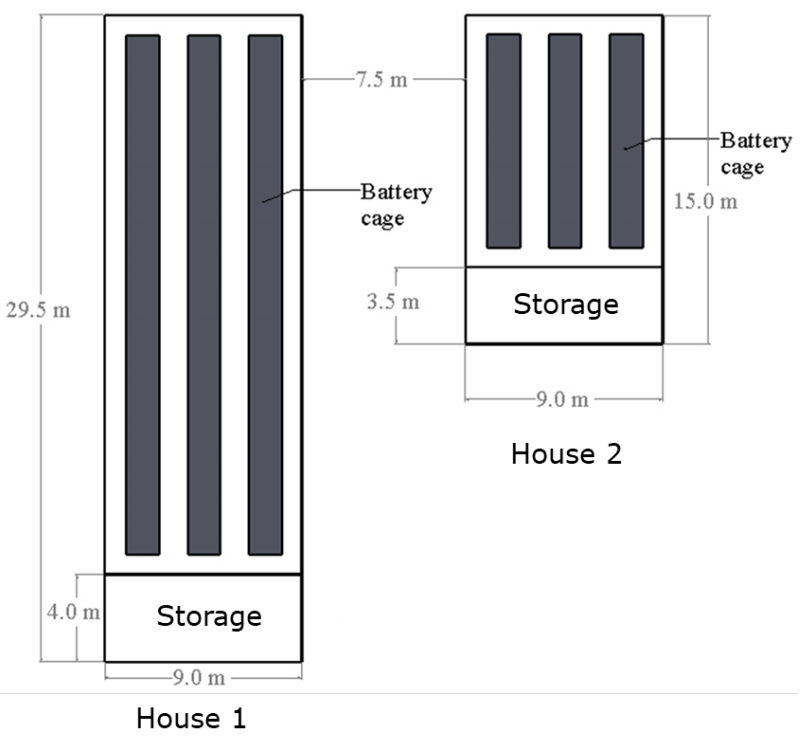

Figure 2. Floor plan view of the experimental site (House 1) showing the surrounding facility (House 2).

Instrumentations. In this study, data acquisition both within the house and the outdoor were hot wire anemometer (HT-9829) for indoor, fan wheel anemometer (AS836) for outdoor and temperature-hygrometer sensors (HTC-1) for both indoor and outdoor. The hot wire anemometer has accuracies of $\pm 1^{\circ} \mathrm{C}$ and $1 \%$ for temperature and air velocity respectively, resolutions of 0.1 and $0.01 \mathrm{~ms}^{-1}$ for temperature and air velocity respectively and measurement ranges of $0-50^{\circ} \mathrm{C}$ and $0.1-$ $25.0 \mathrm{~ms}^{-1}$ for temperature and air velocity respectively. The fan wheel anemometer has measurement ranges of $0-45^{\circ} \mathrm{C}$ and $0.0-45.0 \mathrm{~ms}^{-1}$ for temperature and air velocity respectively, accuracies of $\pm 2^{\circ} \mathrm{C}$ and $\pm 3 \%$ for temperature and air velocity respectively and resolutions of $0.2^{\circ} \mathrm{C}$ and $0.1 \mathrm{~ms}^{-1}$ for temperature and air velocity respectively. The temperaturehygrometer sensor has temperature and humidity measurement ranges of -10 to $+50^{\circ} \mathrm{C}$ and $10-99 \%$ respectively, temperature and humidity resolutions of $0.1^{\circ} \mathrm{C}$ and $1 \%$ respectively and temperature and humidity measuring accuracies of $\pm 2^{\circ} \mathrm{C}$ and $10 \%$ respectively. In this study, only the relative humidity of the temperature-hygrometer sensor was recorded since the other sensors have temperature sensors embedded in them. 


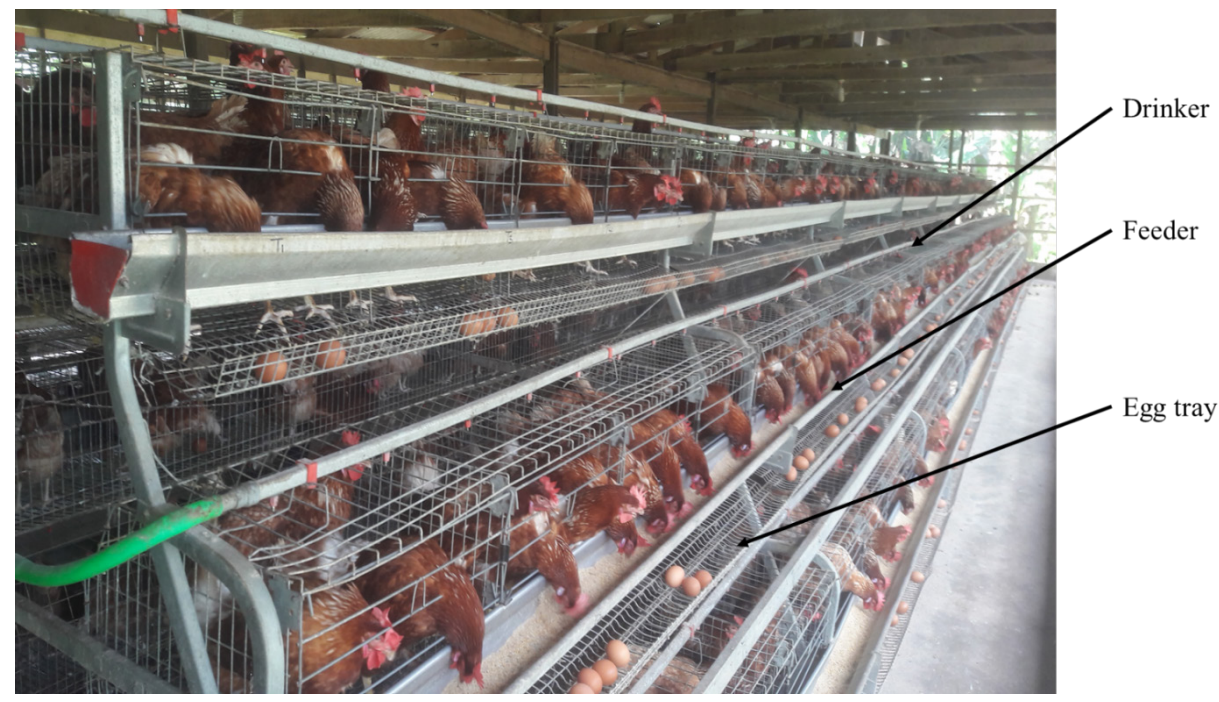

Figure 3. Battery cages with laying birds

Experimental measurements. The measurements obtained during the study were, air temperatures (indoor and outdoor), relative humidity (indoor and outdoor) and air velocity (indoor and outdoor). All the sensors (hot wire anemometer, digital anemometer and temperature-hygrometer sensor) were installed both indoor (at the centre of the house) and outdoor (at the windward side of the house) at the height of $2.5 \mathrm{~m}$ above the floor (Figure 4). The study was conducted over a period of three hours when the climatic condition was considered to be harsh for poultry birds (22). Generally, in Nigeria, the climatic condition starts to be hot around $1100 \mathrm{H}$ and lasts till around $1600 \mathrm{H}$. In this study, the three hours study was conducted between $1100 \mathrm{H}$ and $1400 \mathrm{H}$. The environmental parameters were measured and recorded at an interval of 5 minutes.

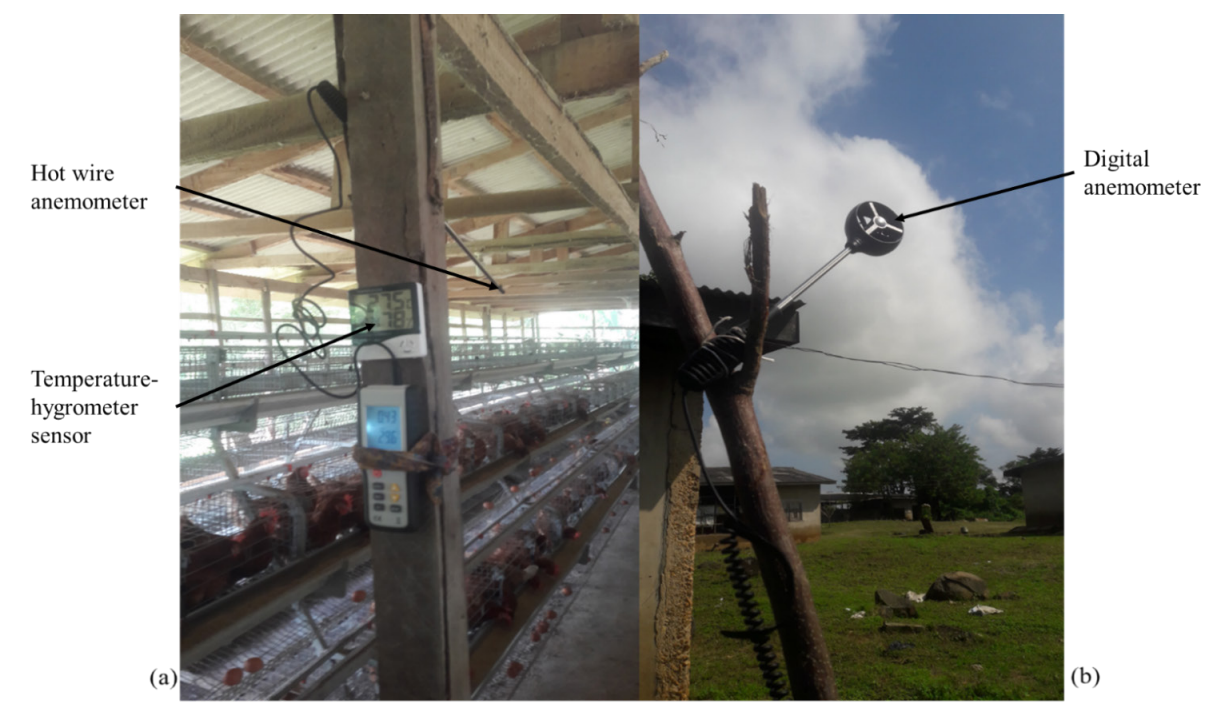

Figure 4. Sensors installations in (a) indoor (hot wire anemometer and temperature-hygrometer sensor) and (b) outdoor (fan wheel anemometer (oriented to the prevailing wind) and temperature-hygrometer sensor).

The heat stress index (THI) to which the laying hens were subjected to in the layer house was estimated using an expression developed by National Oceanic and Atmospheric Administration (NOAA) for the laying hen heat stress index and also used in other studies $(19,23)$. The heat stress index for the laying birds (Equation 1) was developed based on the indoor temperature and relative humidity of the house since the heat stress is mostly assessed by the THI (24). 
THI $(\mathrm{Ti}, \mathrm{Hi})=(9 / 5 \mathrm{Ti}+32)-11 / 2(1-\mathrm{Hi})(9 / 5 T i-26)$

where $\mathrm{T}_{\mathrm{i}}$ is the indoor temperature $\left({ }^{\circ} \mathrm{C}\right)$ and $\mathrm{H}_{\mathrm{i}}$ is the indoor relative humidity (\%).

Data analysis. The data obtained during the study were processed with Microsoft Excel 2016 and analysed with SAS JMP Pro 13. The processed data were subjected to t-test (one tailed) to determine the level of significance between the indoor environmental parameters and the outdoor environmental parameters. The data analysed was subjected to a significance level of $5 \%$.

\section{RESULTS}

Air temperature. The air temperatures variation inside and outside the layer house were measured and analysed. The results of the air temperature measured during the study are shown in Figure 5. The outdoor temperature fluctuated between 29 and $38.4^{\circ} \mathrm{C}$ while the indoor temperature steadily increased from $28.9^{\circ} \mathrm{C}$ to over $33^{\circ} \mathrm{C}$. The panting rate, a potential indicator of heat stress of the laying birds, was monitored by an observer during the study to evaluate the level of heat stress in the building. It was discovered that the panting rate of the birds was high as the temperature increased. The result of the statistical analysis ( $\mathrm{t}$-test) indicated that there was a difference $(\mathrm{p}<0.0001)$ between the mean air temperature inside the house and the air temperature outside the house.

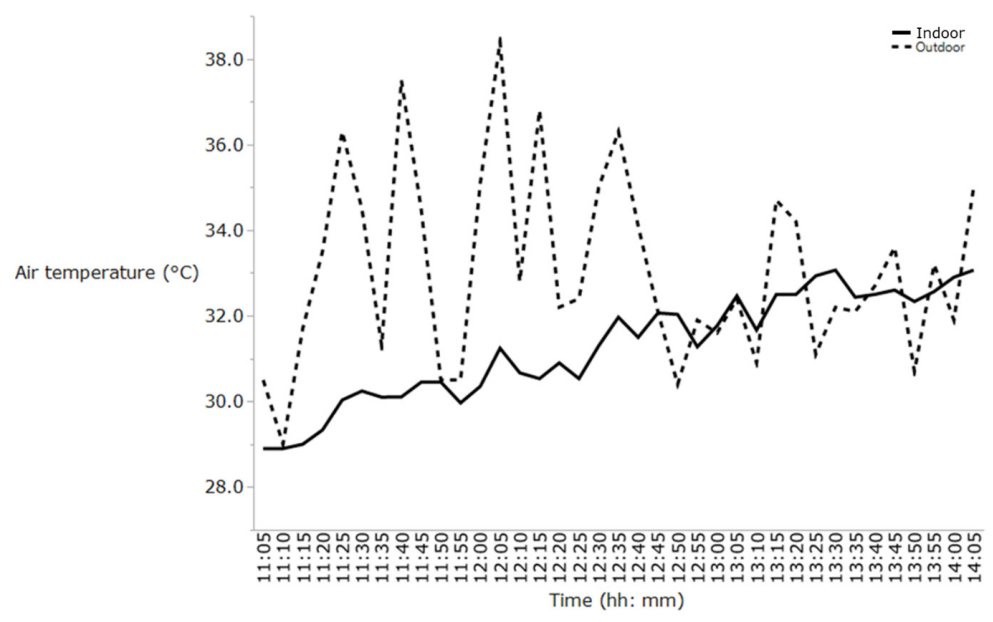

Figure 5. The air temperature inside and outside the laying birds building.

Relative Humidity. Figure 6 shows the relative humidity obtained both within and outside the layer house. As shown in Figure 6, outdoor relative humidity varied between $32.0 \%$ and $50.0 \%$ while the indoor relative humidity was initially high $(79.0 \%)$ and steadily dropped to $59.0 \%$ after three hours. The result of the t-test analysis showed that there was a difference $(p<0.0001)$ between the mean outdoor relative humidity and the mean indoor relative humidity.

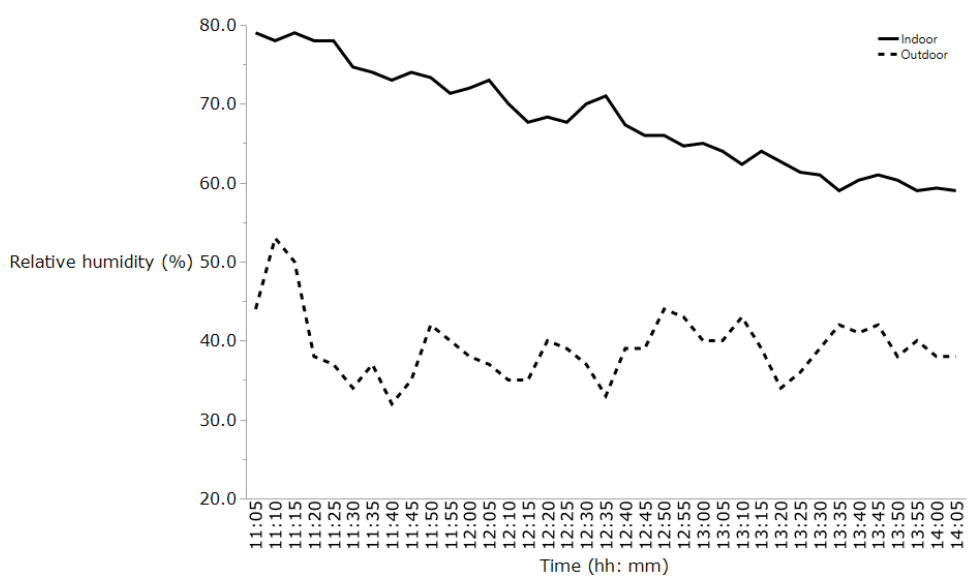

Figure 6. The relative humidity within and outside the layer house. 
Air Velocity. The indoor and outdoor air velocity were evaluated to understand the level of air velocity to which the birds and the building were exposed to during the hot weather periods. Figure 7 illustrates the air velocity measured and recorded over three hours. It could be observed from Figure 7 that the outdoor and the indoor air velocities varied from $0.0 \mathrm{~ms}^{-1}$ to $1.68 \mathrm{~ms}^{-1}$ and $0.07 \mathrm{~ms}^{-1}$ to $0.58 \mathrm{~ms}^{1}$ respectively. The results of the t-test analysis carried out indicated that there was a significant difference $(\mathrm{p}=0.003)$ between the mean air velocity outside the building and the air velocity within the laying birds building.

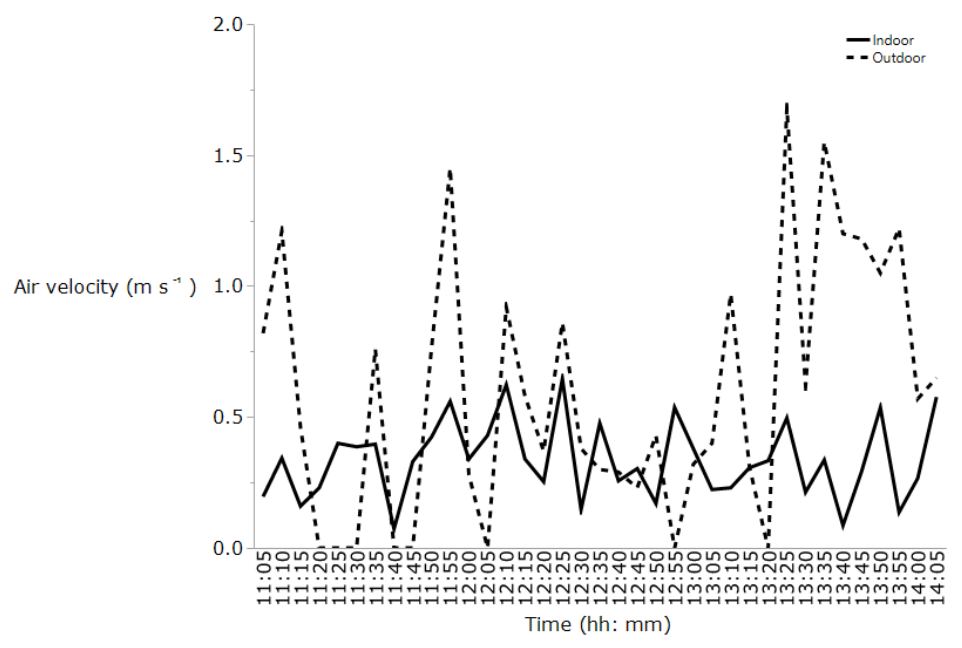

Figure 7. Air velocity inside and outside the layers house.

Layers Heat Stress Index (LHSI). The level of heat stress in the building, using an established heat stress index for laying birds, was estimated based on the temperature and the relative humidity within the building. Figure 8 shows the heat stress index of the layer house over the period that the study was carried out. As it could be observed from Figure 8, the heat stress was high (53.97) at around $1100 \mathrm{H}$ when the study commenced and steadily reduced to 15.93 at around $1400 \mathrm{H}$.

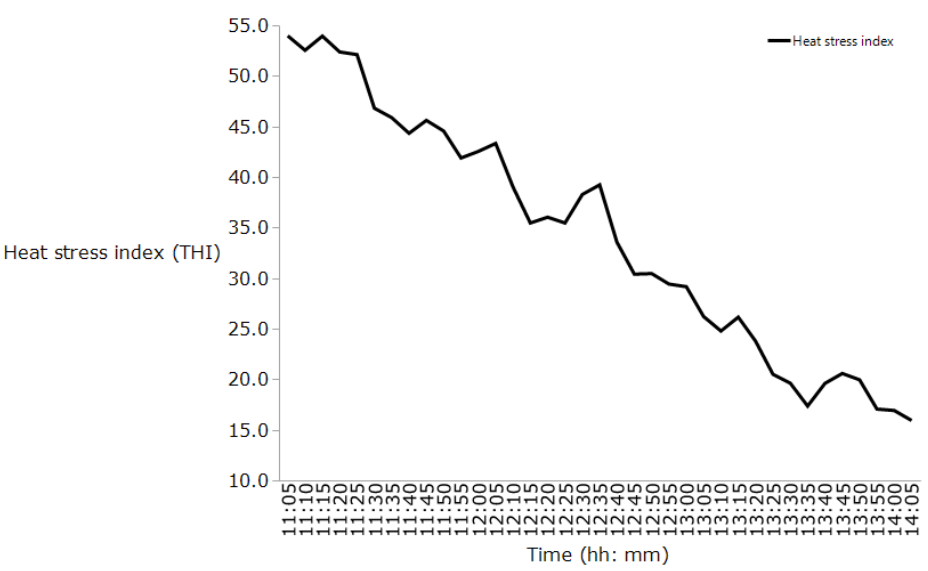

Figure 8. The heat stress index in the layer house

\section{DISCUSSION}

Air temperature. Subjecting poultry to the hot condition has been reported to be detrimental to their welfare and health (25). In this study, it was found that the temperature within the layer house could affect the productivity and normal behaviours of the birds. For laying birds (pullet), the upper critical temperature (UCT) of the thermal comfort zone, as suggested by Chang et al (26), should range between 24 and $26^{\circ} \mathrm{C}$. However, in this study, it has been found that the indoor temperature of the house exceeded the thermal comfort zone required by the birds to thermoregulate easily. Exposing layers to high air temperature could increase their body temperature and could also cause high mortality, poor feed and water consumptions, slow growth rate, poor egg production, and aggressiveness $(27,28,29)$. 
Relative Humidity. The higher indoor relative humidity observed at the onset of the study could have occurred as a result of the low indoor temperature observed when the study commenced. This relationship has earlier been reported by Nilius et al (30). They showed that relative humidity increased as the temperature reduced. Many factors could be responsible for the increase in the relative humidity recorded at the beginning of the study. The contributing factors could be the manure pit directly under the cages, moisture loss during panting and water drops from the drinkers (31). The adverse effects of high temperature and high relative humidity include; heat stress, increased body temperature, hormonal imbalance, poor animal performance, poor heat dissipation, respiratory disorder, disease outbreak, poor egg production, poor feed conversion (32).

Air Velocity. This study has shown that still air condition (no air movement) could occur outside the animal building and that it could significantly affect the air velocity distribution within the animal building. Similarly, the amount of air velocity obtained within the building may not provide adequate air movement required by the birds for their cooling during the weather period. It is expected that the air velocity in poultry building should be capable of preventing excessive heat and dangerous gases that could impair the welfare of birds (22). However, this study has shown that the air velocity in the layer house, where the study was conducted, may not be able to prevent excessive heat and dangerous gases from affecting the welfare of the layer birds. As suggested by Kavolelis et al (33), since the natural ventilation in the building was not sufficient to provide a cool environment for the birds, it is necessary to install fans in the building to improve air distribution, birds' welfare and performances.

Layers Heat Stress Index. The high THI noticed at $1100 \mathrm{H}$ could have been caused by the high relative humidity of $79.0 \%$ measured at the onset of the study. Similar results have been reported in which high heat stress was majorly caused by high relative humidity compared to ambient temperature $(34,35)$. The performance of laying birds greatly depends on the heat stress they are subjected. Duduyemi et al (19), have classified the THI in laying birds as comfortable (<26), heat stress (26.0 - 29.0) and acute heat stress (>29). In this study, based on the report of Duduyemi et al (19), it could be observed that the laying birds in the humid tropical climate are mostly subjected to heat stress and acute heat stress and are less subjected to comfortable conditions during the hotter periods of the day (1100 to $1400 \mathrm{H}$ ). According to Duduyemi et al (19), the performance of laying bird could reduce as the THI increases above the threshold of 27.5 .

In conclusion the indoor environmental parameters and the heat stress index of a laying bird house have been assessed. The results have shown that poultry birds, during the hotter periods of the day, are subjected to high environmental conditions (temperature and humidity) which could be detrimental to their performances. The only mechanism (air velocity) which has been reported to mitigate the impact of hot weather conditions on livestock production has been found to be insufficient as its level in the laying bird building was below $1.5 \mathrm{~ms}^{-1}$ recommended for poultry birds subjected to hot conditions. Similarly, birds are mostly subjected to heat stress throughout their lifetime due to high heat stress which is majorly influenced by high relative humidity.

Therefore, there is a need for ventilation engineers in the humid tropical climate to design and develop a conducive environment for the laying birds which could enhance their performances. The engineers should also develop appropriate ventilation system(s) capable of improving the air movement in the poultry buildings most especially at the animal occupied zone. Further research work could be focussed on evaluating the laying bird building using computational fluid dynamics to understand the airflow pattern and air velocity distribution within the laying bird building. This would also assist the engineers to develop appropriate and suitable buildings for the battery-caged birds in the humid tropical climate.

\section{Acknowledgement}

There was no financial support for this research work. However, the author would like to appreciate the following; Miss Ajayi Temitope, Mr Olodo Sodiq, Mr Ogunsola Babatunde and the Livestock Research Farm workers for their support during the period of data acquisition in the poultry building.

\section{REFERENCES}

1. FAO. Agribusiness Handbook- Poultry meat and eggs. FAO Agribusiness. 2010;65.

2. Mottet A, Tempio G. Global poultry production: Current state and future outlook and challenges. World's Poultry Science Journal. 2017; 73(2):245-56. https://doi.org/10.1017/S0043933917000071 
3. Daghir NJ. Present status and future of the poultry industry in hot regions. In: Daghir NJ, editor. Poultry Production In Hot Climates. 2nd ed. Trowbridge, UK: CAB International; 2008. http://www.itpnews.com/uploads/2014/02/ ITP FILE 07 1.pdf?direct access media=1\#page $=15$

4. Heise H, Crisan A, Theuvsen L. The poultry market in Nigeria: Market structures and potential for investment in the market. International Food and Agribusiness Management Review. 2015; 18(Specia lIssue A):197-222. https:// www.ifama.org/resources/Documents/v18ia/Heise-Crisan-Thevsen.pdf

5. Sahel. An assessment of the Nigerian poultry sector. Vol. 11, Sahel Capital (Mauritius) Limited. Lagos, Nigeria; 2015. http://sahelcp.com/wp-content/uploads/2016/12/Sahel-Newsletter-Volume-11.pdf

6. Trading Economics. Nigeria Temperature. Trading Economics. 2019 [cited 2019 Nov 25]. https://tradingeconomics. com/nigeria/temperature

7. Nmadu JN, Ogidan IO, Omolehin RA. Profitability and resource use efficiency of poultry egg production in Abuja, Nigeria. Kasetsart Journal - Social Sciences. 2014; 35(1):134-46. http://www.thaiscience.info/journals/Article/ TKJS/10960925.pdf

8. Aboki E, Jongur AAU, Onu JI. Productivity and technical efficiency of family poultry production in Kurmi Local Government Area of Taraba State, Nigeria. Journal of Agriculture and Sustainability. 2018; 4(1):52-66. https://doi. org/10.22069/jwfst.2018.15021.1747

9. Afolabi OI, Adegbite DA, Ashaolu OF, Akinbode SO. Profitability and resource-use efficiency in poultry egg farming in Ogun State, Nigeria. African Journal of Business Management. 2013; 7(16):1536-1540. https://doi.org/10.5897/ AJBM2013.6955

10. Tijjani H, Tijani BA, Tijjani AN, Sadiq MA. Economic analysis of poultry egg production in Maiduguri and environs of Borno State, Nigeria. Scholarly Journal of Agricultural Science [Internet]. 2012; 2(12):319-324. https://pdfs. semanticscholar.org/ba8d/b6959d098670104452b96f107356087d1643.pdf

11. Adeyemo AA, Onikoyi MP. Prospects and challenges of large scale commercial poultry production in Nigeria. Agricultural Journal. 2012; 7(6):388-393. http://docsdrive.com/pdfs/medwelljournals/aj/2012/388-393.pdf

12. Ezeh CI, Anyiro CO, Chukwu JA. Technical efficiency in poultry broiler production in Umuahia Capital Territory of Abia State , Nigeria. Greener Journal of Agricultural Sciences. 2012; 2(1):1-7. www.gjournals.org

13. Fontana I, Tullo E, Butterworth A, Guarino M. Broiler Vocalisation to Predict the Growth. In: Proceedings of Measuring Behaviour, Wageningen, The Netherlands. 2014. https://www.measuringbehavior.org/files/2014/Proceedings/ Fontana,\%20I.\%20-\%20MB2014.pdf

14. Ismayilova G. The use of image labelling to identify pig behaviours for the development of a real-time monitoring and control tool. University of Milan; 2013.

15. Chaiyabutr N. Physiological reactions of poultry to heat stress and methods to reduce its effects on poultry production. Thai J Vet Med. 2004; 34(2):17-30. http://www.thaiscience.info/Journals/Article/TJVM/10973644.pdf

16. Ayo JO, Obidi JA, Rekwot PI. Effects of heat stress on the well-being, fertility, and hatchability of chickens in the Northern Guinea Savannah Zone of Nigeria: A review. ISRN Veterinary Science. 2011; 2011:1-10. https://doi. org/10.5402/2011/838606

17. Blanes-Vidal V, Fitas V, Torres A. Differential pressure as a control parameter for ventilation in poultry houses: Effect on air velocity in the zone occupied by animals. Spanish Journal of Agricultural Research. 2007; 5(1):31-37. http:// revistas.inia.es/index.php/sjar/article/viewFile/220/217

18. Vale M, Moura D, Nääs I, Pereira D. Characterization of heat waves affecting mortality rates of broilers between 29 days and market age. Revista Brasileira de Ciência Avícola. 2010; 12(4):279-85. https://doi.org/10.1590/S1516$\underline{635 \times 2010000400010}$

19. Duduyemi OA, Oseni S. Modelling heat stress characteristics on layers' performance traits in southwestern Nigeria. Obafemi Awolowo University; 2012. https://mafiadoc.com/modelling-heat-stress-characteristics-on-layers-tropen tag 5a1c050c1723dd6827915938.html 
20. Kapetanov M, Pajić M, Ljubojević D, Pelić M. Heat stress in poultry industry. Archives of Veterinary Medicine. 2015; 8(2):87-101. https://niv.ns.ac.rs/wp-content/uploads/2016/03/8.Kapetanov.pdf

21. Behura NC, Kumar F, Samal L, Sethy K, Behera K. Use of Temperature-Humidity Index ( THI ) in energy modeling for broiler breeder pullets in hot and humid climatic conditions. Journal of Livestock Science. 2016; 7:75-83. http:// livestockscience.in/wp-content/uploads/brolerodisa.pdf

22. Rojano F, Bournet P-E, Hassouna M, Robin P, Kacira M, Choi CY. Assessment using CFD of the wind direction on the air discharges caused by natural ventilation of a poultry house. Environmental Monitoring and Assessment. 2018; 190(12):724. https://doi.org/10.1007/s10661-018-7105-5

23. Samal L, Sejian V, Bagath M, Krishnan G, Manimaran A, Bhatta R. Different heat stress indices to quantify stress response in livestock and poultry. In: Rao P, editor. Livestock Meteorology. New Delhi, India: New India Publishing Agency; 2017. https://www.ibpbooks.com/livestock-meteorology-hardbound/p/28080

24. Habeeb AA, Gad AE, Atta MA. Temperature-humidity indices as indicators to heat stress of climatic conditions with relation to production and reproduction of farm animals. International Journal of Biometeorology and Recent Advances. 2018; 1(1):35-50. https://doi.org/10.18689/ijbr-1000107

25. Lallo CHO, Cohen J, Rankine D, Taylor M, Cambell J, Stephenson T. Characterizing heat stress on livestock using the temperature humidity index ( THI ) - prospects for a warmer Caribbean. Regional Environmental Change. 2018; 18:2329-2340. https://doi.org/10.1007/s10113-018-1359-x

26. Chang Y, Wang XJ, Feng JH, Zhang MH, Diao HJ, Zhang SS, et al. Real-time variations in body temperature of laying hens with increasing ambient temperature at different relative humidity levels. Poultry Science. 2018; 97:31193125. https://doi.org/10.3382/ps/pey184

27. Zhu W-L, Mu Y, Zhang L, Wang Z. Effect of temperature on body temperature and resting metabolic rate in pups of Eothenomys miletus. Journal of Stress Physiology \& Biochemistry. 2013; 9(1):148-156. https://cyberleninka. $\mathrm{ru} /$ article/n/effect-of-temperature-on-body-temperature-and-resting-metabolic-rate-in-pups-of-eothenomysmiletus/viewer

28. Yoshida N, Fujita M, Nakahara M, Kuwahara T, Kawakami SI, Bungo T. Effect of high environmental temperature on egg production, serum lipoproteins and follicle steroid hormones in laying hens. Journal of Poultry Science. 2011; 48(3):207-211. https://doi.org/10.2141/jpsa.010126

29. Olczak K, Nowicki J, Klocek C. Pig behaviour in relation to weather conditions - A review. Annals of Animal Science. 2015; 15(3):601-610. https://doi.org/10.1515/aoas-2015-0024

30. Nilius G, Domanski U, Schroeder M, Woehrle H, Graml A, Franke KJ. Mask humidity during CPAP: Influence of ambient temperature, heated humidification and heated tubing. Nature and Science of Sleep. 2018; 10:135-42. https://doi. org/10.2147/NSS.S158856

31. Jones DD, Friday WH, Deforest SS. Environmental control for confinement livestock housing. Historical Documents of the Purdue Cooperative Extension Service. 2015; (Paper 1083). http://docs.lib.purdue.edu/agext/1083

32. Okpara MO, Egbu CF, Ani AO. Effect of relative humidity on the performance of Nera Black hens in a humid tropical environment. Journal of Agriculture and Ecology Research International. 2016; 9(1):1-5. https://doi.org/10.9734/ IAERI/2016/18980

33. Kavolelis B, Bleizgys R, Česna J. Natural ventilation of animal sheds due to thermal buoyancy and wind. Journal of Environmental Engineering and Landscape Management. 2008; 16(4):188-94. https://doi.org/10.3846/1648$\underline{6897.2008 .16 .188-194}$

34. Raymond C, Singh D, Horton RM. Spatiotemporal Patterns and Synoptics of Extreme Wet-Bulb Temperature in the Contiguous United States. Journal of Geophysical Research: Atmospheres. 2017; 122(24):108-113. https://doi. org/10.1002/2017JD027140

35. Sherwood SC. How Important Is Humidity in Heat Stress? Journal of Geophysical Research: Atmospheres. 2018; 123(21):808-810. https://doi.org/10.1029/2018JD028969 